\title{
PERTEV TEVFiK VE 'VATAN TEHLiKEDE' isiMLi RISALESi
}

\section{Pertev Tevfik and His Tractate Titled as 'Homeland Endangered' Dr. Taner ASLAN"}

\begin{abstract}
ÖZ
Pertev Tevfik Bey tarafindan kaleme alınan 'Vatan Tehlikede' isimli risale, ittihat ve Terakki Cemiyeti'nin uygulamalarını ve Süleyman Nazifi Hak gazetesinde 25 Temmuz 1912 tarihinde yayımladığı "Kılıçlı Siyaset" başlıklı makalesiyle eleştirmektedir. Tevfik Bey, Meşrutiyetin ilanının üzerinden dört yıl geçmesine rağmen Meşrutiyetin ruhuna uygun bir yönetim ve adaletin tesis edilemediğini; dolayısıyla hürriyet ve eşitliğin olmadığı ortamda, kaosun ve kargaşanın hakim olacağını belirtmektedir. İttihat ve Terakki üzerine eleştirisini, Cemiyetin hükümetlere müdahale etmesi, ordunun siyasete karışması, tekelci bir siyasî tavır takınması, başka siyasî oluşumlara hayat hakkı tanımaması, seçimlere müdahale ederek demokrasi ortamının oluşmasına engel olması şeklinde yapmıştır. Çalışmada, 11. Meşrutiyet Döneminin demokrat kimliğiyle öne çıkmış önemli simalarından Pertev Tevfik ve 'Vatan Tehlikede' isimli risalesi ele alınmıştır.
\end{abstract}

Anahtar Sözcükler: Pertev Tevfik Bey, Vatan Tehlikede, Meşrutiyet

\section{ABSTRACT}

Written by Mr. Pertev Tevfik, the tractate named 'Homeland Endangered' criticizes the practices of Committee of Union and Progress, and Suleyman Nazifs essay titled as "Politic with a Sword" published in the newspaper "Rights" on July 25, 1912. Mr. Tevfik states that, even after four years following the declaration of the Constitution, justice and an administration in the spirit of constitutional monarchy could not be established, resulting in a reign of chaos and confusion where liberty and equality cannot prevail. He based his critique on Committee of Union and Progress on subjects such as the Committee's interference on governments, the army's interference in politics, adoption of a monopolistic stance, the blocking of other political formations, lack of democracy due to interfering in elections. The study makes an analysis on the tractate titled as "Homeland Endangered" and Pertev Tevfik, who is a prominent political identity of the Second Constitutional Period.

Key Words: Pertev Tevfik, Homeland Endangered, Constitutional

\section{Giriş}

24 Temmuz 1908'de ilan edilen Meşrutiyet, bütün gazetelerde büyük bir 'hoşamedî̀ ile karşılanmıştır'. İstanbul gazeteleri, Meşrutiyetin ilanı sabahında Meclis-i Mebusan'ı toplantıya çağıran resmî tebliği yayınlayarak Meşrutiyetin

\footnotetext{
*Aksaray Üniversitesi Fen Edebiyat Fakültesi Tarih Bölümü Öğretim Üyesi. Kampus/Aksaray. e-post: taner.aslan4@gmail.com

' Haftalık mizah gazetesi Davul, "Davul ceridesi, hürriyeti ilan etmek, Cemiyeti alkışlamak için, askerî teşci, milletimizi teşvîk, herkesi vazîfesine davet için uğraşıyor" diyordu. Davul, numara l, 14 Teşrîn-i Evvel 1324, s.l.
} 
resmen ilan edildiğini sütunlarından duyurmuşlardır ${ }^{2}$. Gazete sütunlarında hürriyete dair yazılar kaleme alınarak hürriyetin kazanımlarından bahsedilmiştir ${ }^{3}$. Hürriyetin ilanını halk büyük bir memnuniyetle karşılamış, sevinç gösterileri düzenlemiştir. Bu sevinç öyle bir hal almış ki papazlarla hocalar birbirlerine sarılarak, Meşrutiyetin ilanından duydukları memnuniyeti göstermişlerdir ${ }^{4}$. Meşrutiyetin ilanı büyük bir gün olarak ifade edilmiş, ${ }^{5}$ Meşrutiyeti ilan edenler hürriyet perisi gibi görülmüştür. Dönemin yazarları, Meşrutiyet uğrunda çok çileler çekildiğinden ve bunun kolay elde edilmediğinden bahsederek, buna destek verilmesinden ve hizmet edilmesinden, Meşrutiyeti ilan edenlere de yardımda bulunulması gereğinden bahsetmişlerdir ${ }^{6}$.

Yurt içinde olduğu gibi yurt dışında da Meşrutiyetin ilanı büyük yankı bulmuş, İran, İtalya, Amerika, Avusturya - Macaristan, İspanya, Belçika sefirleriyle Fransa, İngiltere, Almanya sefaretinden ve Karadağ maslahatgüzarından oluşan bir grup, Padişahı ziyaret ederek, Kanun-i Esasi'nin ilanından duydukları memnuniyeti dile getirerek, onu kutlamışlardır. Meşrutiyetin ilanı yabancı basının da önemli gündem maddesini oluşturmuştur. Örneğin Pinon René Revue des Deux Mondes gazetesinde 1 Eylül 1908'de yayımlanan 'La Turquie Nouvelle' başlıklı yazıda, Meşrutiyetin ilanının Osmanlı Devleti'nde yeni bir dönem başlattığı, herkesin büyük bir umut beslediği anlatılmıştır ${ }^{8}$.

İttihat ve Terakki Cemiyeti, 19 yıllık mücadeleden sonra kansız bir darbe ile ülkeyi yeniden meşrutî bir sisteme kavuşturarak amacına ulaşmakla, Osmanlı

\footnotetext{
${ }^{2}$ Ahmet Refik (Altınay), Inkılab-ı Azim, Asır Matbaası, ìstanbul, 1324/1908, s.86.; ikdam, numara 5087, 11 Temmuz 1324/24 Temmuz 1908; Sabah, numara 6783, 11 Temmuz 1324/24 Temmuz 1908, s.1.

3 "Hürriyet Nedir?", Davul, 21 Teşrîn-i Evvel 1324, s.7.

4 “Vatandaşlarımızı Tebrik", Ișık Dergisi, numara 3, İstanbul, 1325, s.2; Cemal Kutay, Prens Sabahattin Bey, Sultan II. Abdülhamit, Ittihat ve Terakki, Tarih Yayınları, İstanbul, 1964, s.215; Yusuf Hikmet Bayur, Türk Inkılabı Tarihi, Cilt 2, T.T.K., Ankara, 1991, s.65; Hasan Amca, Doğmayan Hürriyet, Sıralar Matbaası, ìstanbul, 1958, s.10 vd.

${ }^{5}$ Ahmet Ziya, Meşrutiyet Uğrunda, Yeni Osmanlı Matbaa ve Kütüphanesi, i̇stanbul, 1327,s.1-47.

${ }^{6}$ Ekrem Reşad - Osman Ferid, 10 Temmuz Hatırası, 1325 Sene-i maliyesine Mahsûs Nevsal-i Osmanî, Matbaa-i Ahmet îhsan, İstanbul, 1325 (1909), 208 s.; Fatma Teryal Meşrutiyetin ilanıyla esaretten kurtulunduğundan bahseder; "Devr-i menfûr-1 istibdadın dest-i tazyîkinde ezildiğimiz esnalarda düşündüğümüzü hatırladığımızı istediğimiz gibi söyleyip yazamazdık. Lakin bi-inayetullah Resne dağlarından peri-i hürriyet gibi meydan-1 zuhûra çıkan Niyaziler, Enverler, Atıflar, Salimler gibi kahramanlarla şanlı ordumuz sayesinde ağzımıza vurulan o dehhaş kilidi çektik kopardık, zalimlerin sima-yı mülevvesine attık. Esaretten halas olduk. İşte bu gün mağsûb hakkımızı istirdada kendimizde hak görerek şu eser-i acizanemi alem-i insaniyete arz eyliyorum..." Bkz. Fatma Teryal, Hakikat, Cilt 1, ìstanbul, 1325, s.2.

${ }^{7}$ BOA, DuiT (Dahiliye Usulü İradeler Tasnifi), 49/11-3-5/3/1, 2.

${ }^{8}$ Bkz; Paul Imbert, Osmanlı Imparatorluğu'nda Yenileşme Hareketleri, (Türkiye'nin Meseleleri), (çev. Adnan Cemgil), Havass Yayınları, İstanbul, 1981, s.122-123.
} 

$45 * 63$

Devleti için yeni bir dönem başlatmıştır'. Meşrutiyetin ilanından sonra illegal olarak faaliyet gösteren Cemiyet açığa çıkmış, Meşrutiyetin ilanında büyük gayret ve fedakârlıkları olan Talat, Rahmi, Necip, Hüseyin ve Baha Beylerden oluşan bir grup Selanik'ten i̇stanbul'a gelmiş̧lerdir ${ }^{10}$.

Meşrutiyet ilan edilmişti; ancak, Meşrutiyetin ilanında müessir rol oynamış olan İttihatçılar, nasıl bir yol takip edeceklerini tespit edemeyerek, idareyi sabık dönemin idarecilerine bırakmak durumunda kalmışlardır".

Meşrutiyetin istiklal ve bekayı temin edebileceğine inanılmış, ancak çok geçmeden müthiş bir hayal kırıklığı yaşanmıştır' ${ }^{12}$ Halk, Meşrutiyete dair malumata sahip değildi. Bunun manasını bilmediğinden, ${ }^{13}$ hürriyetin serbestlik getirdiği düşüncesinden hareketle, sabık devrin memurlarından öç almaya başlamıştı $1^{14}$.

İttihat ve Terakki Cemiyeti, perde arkasından hükümetleri denetlemeye ve dolaylı olarak etkilemeye çalışmıştır' yapısıyla gayrı resmî olarak kuvvetlendiği nispette ise resmî olarak hemen her hükümet icraatını ve siyasî gelişmeleri yönlendirmeye çalışırken, diğer taraftan da kendi dışında bir siyasî, hatta sosyal cemiyetlere hayat hakkı tanımayan tutumu' $^{\prime 6}$ ile aşırı siyasallaşma ve hizipleşme, toplumsal gerilim meydana

${ }^{9}$ BOA, YEE (Yıldız Esas Evrakı), 23/1792; Hasan Amca, a.g.e., s.10 vd. O dönemi yaşamış Dahiliye Nezareti'nden emekli Mehmet Memduh Bey, Kanun-i Esasi'nin ilanı ile ilgili olarak şunları söylemiştir; "Devlet-i Osmaniyye istibdad ile payidar olamayacağından taklîb-i idare elzem idiğine çoktan kaniydim. Zaman şu emniye-i mes'udeyi suhûletle ihsan eyledi. İnkılabımız avanında azim-i şükre şayandır ki Avrupa devletlerinin takallübat-ı ezmanında olduğu gibi çok çok kanlar dökülmedi. Hanümanlar yıkılmadı. Buna en başlı sebeplerden biri de iftihar-ı bişmar ile söylerim zabıta-i manevîyye tabîr-i essahla hüsn-i i'tikad millet-i i̇slamiyyedir." Bkz. Mehmet Memduh Paşa, Feveran-ı Ezman, Vilayet Matbaası, İzmir, 1915, s.12; Mehmet Memduh'un mezkur eseri Ahmet Nezih Galitekin tarafindan Tanzimat'tan Meşrutiyete Mehmet Memduh adı ile yayına hazırlanmıştır. Eser 1995'te Nehir Yayınları tarafından yayımlanmıştır.

${ }^{10}$ Ekrem Reşad - Osman Ferid, a.g.e., s. 201.

"Hüseyin Cahit Yalçın, Talat Paşa, Yediğün Neşriyat, İstanbul, 1943, s.14, 34; Feroz Ahmad, ittihat ve Terakki (1908-1914), (çev. Nuran Yavuz), Kaynak Yayınları, İstanbul, 1984, s.38.

${ }^{12}$ Hasan Amca, a.g.e., s.49, 62.

${ }^{13}$ Ahmad, a.g.e., s.35.

${ }^{14}$ Yalçın, a.g.e., s.16.

${ }^{15}$ M.Z., Ittihat ve Terakki Cemiyeti'nin Firıldakları yahut Tarih-i Matem, ìstanbul, 1328, s.8.

${ }^{16}$ Ali Birinci, Hürriyet ve Itilaf Fırkası, Dergah Yayınları, İstanbul, 1990, s.16. Şerif Paşa, Cemiyetin fırka hayatını kendisinden başka kimseye münasip görmediğini, herkesin her vatan ferdinin memleketi için, vatandaşlarının ikbali, geleceği için düşünmek, o yolda çaba harcamak hakkına sahipken Cemiyetin bu vadide "istibdad"a geçmişe rücu eylediğini, Meşrutiyetin ancak partilerle, millî kuruluşların denetimi altında feyizli bir şekilde yerleşebileceğini, partiyi istememenin yaptıklarından sorguya çekilmemeyi istemek, sorumsuz olmak demek olduğunu, hal böyle olduğu için basında önemli mücadeleler, cereyanlar doğmaya, şikayetlerin birbirini izlemeye ve basının müthiş bir hürriyet buhranı geçirmeye başladığını, bütün partileri 
$64^{* \text { TAED }} 45$

getirerek, İttihatçı muhalifliği ortaya çıkartmıştır. Bunun yanında Cemiyetin herkesi "hamiyet, vatan-perestlik ve fikr-i terakki"yi inhisar altında tutmaya çalışması da Cemiyet karşıtlığının en önemli sebepleri arasında yer almıştır ${ }^{17}$. Ayrica memur terfilerinin keyfi bir şekilde yürütülmesi, ${ }^{18}$ Cemiyetin güvendiği yandaşlarını Bab-ı Ali ve devlet bürokrasisinde istihdam etmek istemesi, ${ }^{19}$ kadro fazlası memurların işten çıkartılması ${ }^{20}$ da Cemiyet karşıtlığının oluşmasına zemin hazırlamıştır. Bu siyasî vaziyet karşısında oluşan muhalif grup, Cemiyetin hatalarını basın yayın yoluyla dillendirmeye başlamıştır. Cemiyet muhalifleri arasında demokrat kimliğiyle ön plana çıkan Pertev Tevfik Bey de yer almıştır. Bu çalışmada, muhaliflerden Pertev Tevfik'in İttihatçıları tenkit ettiği Vatan Tehlikede isimli risalesi ele alınmıştır.

\section{Pertev Tevfik}

"ịstibdad" idaresinin memleketin gelişmesinin önünü tıkadığını, hür fikirleri ortadan kaldırdığını düşünen; meşrutiyetçi, demokrat ve "fuzala-yı ahrar" kimliğiyle bilinen Pertev Tevfik Bey'in hayatına dair bilgiler çok mahduttur. Soyadı Kanunu'nun çıkartılmasından sonra aldığı Ahrar (hürler) soyadı, onun hürriyete olan aşkının bir sonucudur. Askerî Tıbbiye'ye girer, ancak Tıbbiye'nin birinci sınıfından 31 Mart Hadisesi ile alakası olduğu töhmetiyle İttihatçılar tarafındayken uzaklaştırıır. Tıbbiye'den atıldıktan sonra Paris'e gider ve orada Şerif Paşa'nın hususî kâtipliğini ve ìstanbul'daki muhalefet gruplarıyla Paşa arasında bağ kurarak onun vekilharçlı̆̆ını yapar ${ }^{21}$. Gençlik yıllarında siyasî hayata atılan Tevfik Bey, İstanbul'da neşriyat hareketlerinde bulunur.

Pertev Tevfik'in Şerif Paşa'nın özel işlerini yapması, ona maddî ve siyasî faaliyetler açısından büyük fayda sağlar. Şerif Paşa, babasından kalan servetiyle Paris'te muhaliflerin finansmanın temin eder. Pertev Tevfik de bu finansmandan

\footnotetext{
memleket için zararlı görmesiyle Cemiyetin aslında mevcudiyetine kasdeylediğini ifade eder. Cemiyetin kendinden başka oluşumlara hayat hakkı tanımadığı tekelci tutumuyla türlü saikler altında iftiralarla Fedakaran-1 Millet Cemiyeti'ni adeta kahredercesine çiğnediğini, koca kahramanların mukaddes, muazzez, unvanlarıyla, hükümlerini zorbaca yürütme amacıyla İttihad'ın gizli kuvveti bütün gücünü hileye, zorbalığa verdiğini, artık asker, bazı subayların Meclis-i Mebusan koridorlarını muhasara altına almaya, Bab-ı Ali'yi dolaşmaya başladıklarını belirtir. Bkz; Şerif Paşa, Bir Muhalifin Hatıraları -itttihad ve Terakkiye Muhalefet-, Nehir Yayınları, ìstanbul, 1990, s. 30-31.

${ }^{17}$ Şerif Paşa, a.g.e., s.23-24.

${ }^{18}$ Bayur, a.g.e., Cilt 3, s.90-91.

${ }^{19}$ Ahmet Turan Alkan, II. Meşrutiyet Döneminde Ordu ve Siyaset, Cedit Yayınları, Ankara, 1992, s.116.

${ }^{20}$ BOA, Y.EE (Yıldız Esas Evrakı), 86/32, sıra no: 3186.

${ }^{21}$ Birinci, a.g.e., s.83; Galip Vardar, Ittihat ve Terakki lçinde Dönenler, (haz. Samih Nafiz Tansu), Yeni Zamanlar, ìstanbul, 2003, s.251.
} 
faydalanır. Keza onun Muahede adıyla neşrettiği gazete için maddi kaynağı Şerif Paşa'dan sağlamış olması muhtemeldir.

Pertev Tevfik'in siyasî mücadelesi talebelik yıllarına rastlar. Daha talebe iken gizli bir cemiyet olan Selamet-i Umumiye Kulübü'nün kurucuları arasında yer alır. Cemiyetin bütün çalışmalarında aktif bir rol oynar. Bu Cemiyetin kurucuları demokrat kimlikleriyle öne çıkar. Hukuk talebelerinin bu ismi seçmesinde o tarihlerde Mülkiye Mektebi'nin tarih hocalığını yapan Murat Bey'in derslerde Fransız Devriminin "Convantion" döneminden ve bu Meclis'in olağanüstü yetkilere sahip devrimci Comité du Salut Public (Selamet-i Umumiye Heyeti)'den bahsetmesinin etkisi olduğu söylenebilir ${ }^{22}$.

11. Meşrutiyetin siyasal ortamının renkli simalarından Pertev Tevfik Bey, 6 Şubat 1909 tarihinde kurulan Osmanlı Demokrat Fırkası (Fırka-i ibad)'nın kurucuları arasında da yer alır ${ }^{23}$. Bu Cemiyetin kurulmasının temelinde İttihat ve Terakki'nin kamuoyunda uyandırdığı hoşnutsuzluk yatar. İttihat ve Terakki muhalifleri, bu durumdan faydalanmak için söz konusu Cemiyeti teşekkül ettirirler $^{24}$. Pertev Tevfik'in hareketli siyasî yaşamı bundan sonra artarak devam eder. Daha sonra 1909 yılının sonlarında Paris'te kurulan Islahat-ı Esasiye-i Osmaniye Fırkası içinde Şerif Paşa, Ali Kemal, Mevlanzade Rıfat, Dr. Refik Nevzat, Albert Fua, Kemal Avni Beyler ile birlikte kurucu olarak yer alır ${ }^{25}$.

Pertev Tevfik Bey, Muahede gazetesinde Meşrutiyet hükümetinin uygulamalarını tenkit ettiği bir yazısından dolayı Divan-ı Harb-i Örfi'ce hapse mahkûm olur ${ }^{26}$. Ancak gazetede buna dair bir malumata rastlanmaz. Pertev Tevfik bir sosyalist olmasa da Osmanlı Sosyalist Fırkası́nın kuruluşunda yer alır. Onun birçok fırkanın kuruluşunda yer almasını İttihatçı muhalifliğinde aramak makul görünmektedir ${ }^{27}$. Pertev Tevfik Bey, sosyalist fırkanın içinde bulunduysa da sosyalist değil, demokrat bir şahsiyettir. Keza, gazetesi Muahede sosyalistlikle ilgisi olmayan demokrat bir gazetedir. Osmanlı Sosyalist Fırkası'nın ileri gelenleri

\footnotetext{
${ }^{22}$ Tarık Zafer Tunaya, Türkiye'de Siyasal Partiler, Cilt 1, iletişim Yayınları, İstanbul, 2007, s.206; Firuzan Hüsrev Tökin, Türk Tarihinde Siyasi Partiler ve Siyasi Düşüncenin Gelişsmesi, Elif Yay., istanbul, 1965, s.45.

${ }^{23}$ Tunaya, a.g.e., s.205.

${ }^{24}$ Tunaya, a.g.e., s.206.

${ }^{25}$ Tunaya, a.g.e., s.252.

${ }^{26}$ Tunaya, a.g.e., s.268. 12 Teşrin-i evvel 1326 tarihli Muahede gazetesinde "Rıza Nur Bey Tahliye Edildi" manşeti ile neşredilen makalenin sahibi Dr. Ali Baha Efendi ve gazetenin mesul müdür ve sahibi Pertev Tevfik Efendi'nin bulunarak Divan-ı Harbe gönderilmelerine dair arşivde bir bilgi yer almaktadır. BOA, DH.EUM.KADL., $1 / 12$.

${ }^{27}$ Tunaya, a.g.e., s. 278.
} 
$66^{*}{ }^{\text {TAED }} 45$

arasında görünmesi de pek olası değildir. Pertev Tevfik Bey solcuları manen destekler ${ }^{28}$.

Meşrutiyetin ilanından bir yıl sonra siyasal ortam bunalımlı bir hal alır. İttihatçılar ve onların muhalifi İtilafçılar arasında kıyasıya bir rekabet yaşanır. Bu rekabet ortamı içinde 31 Mart Hadisesini askerî tedbirlerle bastıran Mahmut Şevket Paşa'nın öldürülmesi siyasî zemini daha kaygan hâle getirir. Mahmut Şevket Paşa'nın öldürülmesinde İtilafçılar ön planda görülür. 31 Mart'tan sonra sıkıyönetim sonucunda oluşturulan Divan-ı Harp, İtilafçı liderleri ve başka ünlü kişileri gıyaben idama mahkûm eder ${ }^{29}$. Tevfik Çavdar da Çerkez Kazım ile Pertev Tevfik'in Mahmut Şevket Paşa'ya tetik çektiğini iddia ederse de Ali Birinci, Çavdar'ın onu Topal Tevfik'le karıştırdığını belirtir ${ }^{30}$.

Divan-1 Harb-i Örfi'nin hakkında gıyabî idam kararını vermesinden sonra yurda dönmeyen Pertev Tevfik Bey, siyasî mücadelesine Paris'te devam ederek, Şerif Paşa'nın reisliğinde kurulan Millî Muhalefet Fırkası içinde yer alır ${ }^{31}$. Pertev Tevfik Bey, Şerif Paşa ile Fırka'nın malî münasebetlerini sağlar ${ }^{32}$.

Tevfik Bey'in fikri yapısında demokrasi ve özgürlükler ön plandadır. Memleketin ilerlemesi ve gelişmesi için Batılılaşmak gerektiğini, Batı Medeniyeti'nin gelişmesini ve ilerlemesini örnek almakta beis olmadığını, ancak onu bütünüyle taklit etmenin bizim gelişmemizin ve ilerlemememizin önünü tıkayacağını öne sürer ${ }^{33}$. Devletin sorunlarının ortadan kalkması için her bir Osmanlı vatandaşının vazife ve mesuliyet duygusu içinde hareket etmesi gerektiğini vurgulayan Tevfik Bey, Batı'daki prensip ve disiplinin de memleketimizde tatbik edilmesi gerektiğini belirtir ${ }^{34}$. Demokrasi mesleğine yürekten bağlı olan Tevfik Bey, Osmanlı Devleti'nin bekasının ve ilerlemesinin teminatı olarak demokrasiyi görür. Devletin ve milletin her meselesinin demokrasi içinde halledilmesinin gereğine işaret eder. Demokrasinin milleti tenvir ettiğini, intibahı ve terakkiyi tesis ettiğini, eşitliği ve hukukun üstünlüğünü sağladığını ifade eder ${ }^{35}$.

\footnotetext{
${ }^{28}$ Mete Tunçay, Türkiye'de Sol Akımlar, Cilt 1, Bilgi Yayınevi, İstanbul, 1978, s.41; Tunaya, a.g.e. s.303.

${ }^{29}$ Vardar, a.g.e., s.261.

${ }^{30}$ Birinci, a.g.e., s.209.

${ }^{31}$ Tunaya, a.g.e., s.314.

${ }^{32}$ Ali Birinci, Tarihin Gölgesinde, Dergâh Yayınları, İstanbul, 2001, s.388.

${ }^{33}$ Pertev Tevfik, "Bizde Matbuat", Muahede, numara 8, 12 Teşrin-i evvel 1326 Salı, s.l.

${ }^{34}$ Pertev Tevfik, "Intizam Vazife", Muahede, numara 9, 13 Teşrin-i evvel 1326 Çarşamba, s.l.

${ }^{35}$ Pertev Tevfik, "Muahede'nin Tefrikası Demokrasi 1", Muahede, numara 19, 1 Kanun-ı evvel 1326 Çarşamba, s.2.
} 
Meşrutiyetin ilanı sonrasında Meşrutiyetin getirdiği özgürlük ortamında yüzlerce cemiyet ile sayısız gazete ve mecmuanın kurulduğuna şahit olunmuştur ${ }^{36}$.

\section{Pertev Tevfik'in “Vatan Tehlikede" ìsimli Risalesi}

ìttihat ve Terakki Cemiyeti, faaliyetlerini ve fikirlerini gazete, broşür ve risalelerle duyurmaya çalışmıştır. Cemiyet, Meşrutiyet öncesinde Abdülhamit idaresinin menfî yönlerini "Vatan Tehlikede" isimli risale de ele almıştır. Il. Meşrutiyetten sonra Meşrutiyet ve Kanun-i Esasi etrafinda toplananlar arasında çıkar çatışmasının yaşanması, özellikle İttihat ve Terakki Cemiyeti'nin tekelci tutumu muhalif bir grup ortaya çıkartmış, ${ }^{37}$ bu muhalif grup ittihat ve Terakki Cemiyeti'nin Meşrutiyet öncesinde vatanın tehlikede olduğuna dair yayımladığı risalelere benzer risaleler yayımlamışlardır. Muhalifler, İttihatçıların "Vatan Tehlikede" adıyla yayımladığı risaleye gönderme yaparak, bu kez vatanın itttihatçılar elinde tehlikede olduğunu vurgulamışlardır.

Tevfik Bey, Süleyman Nazif Bey'in İttihat ve Terakki Cemiyeti tarafindan kurulan Hak gazetesinde yazmış olduğu ${ }^{38}$ "Kılıçlı Siyaset" isimli makalesi ${ }^{39}$ üzerine "Vatan Tehlikede" isimli risaleyi kaleme almıştır. Risalenin, Süleyman Nazif Bey'in $H a k$ gazetesinde neşrettiği makaleler üzerine kurgulandığını söyleyebiliriz. Nazif Bey, bu gazetede yazmaya başladığında, -belki de Cemiyetin gazetesi olması hasebiyle bir temenni olarak- 11. Meşrutiyete kadar biriken sorunların, sıkıntıların ve aksaklıkların ìttihat ve Terakki Cemiyeti tarafindan ortadan kaldırılacağına, düzeltileceğine, hatta vatanın tek kurtuluşu için bu fırka/cemiyeti göstermesi, onun programıla intibahın gerçekleşebileceğine inanır. İttihat ve Terakki'nin 1912 seçimlerinden zaferle çımış olmasını büyük bir memnuniyetle karşılamıştır ${ }^{40}$. Bu durum Tevfik Bey'in, Nazif Bey'i eleştirmesindeki en önemli sebep olarak görülmektedir. Fakat Süleyman Nazif bu temennisini hep hüsn ü zan ile yapmıştır. Özellikle itttihat ve Terakki'nin şahsi hırs ve emellerini memleketin menfaatlerinin önünde tutması; fırka kavgaları ve İtalya karşısındaki acizlik yüzünden itimadı sarsılır ${ }^{41}$. Tevfik Fikret de Süleyman Nazifi İttihat ve Terakki Cemiyeti'ne kâh muvafakat, kâh muhalefet eden edebî bir kişilik olarak belirtir ${ }^{42}$.

${ }^{36}$ Birinci, a.g.e., 2001, s.152.

${ }^{37}$ Birinci, a.g.e., 2001, s.31-33.

${ }^{38}$ Abdülhak Şinasi, "Süleyman Nazife Dair Hatıralar", Muhit, no 29, Mart 1931, s.29-32.

${ }^{39}$ Süleyman Nazif, "Kılıçlı Siyaset", Hak, 25 Temmuz 1912.

${ }^{40}$ Süleyman Nazif, "itttihat ve Terakki'de Celal Nuri Bey”, Hak, 27 Mart 1912; Süleyman Nazif,

"Bursa'da Salihanizade Ragıb Beyefendiye Cevab", Hak, 31 Mart 1912.

${ }^{41}$ Şuayb Karakaş, Süleyman Nazif, KB, Ankara, 1988, s.97.

${ }^{42}$ Şevket Beysanoğlu, Doğumunun 10o. Yılında Süleyman Nazif (Hayatı, Sanatı, Eserlerinden Seçmeler), Ankara, 1970, s.108. 
$68^{*}{ }^{\text {TAED }} 45$

Tevfik Bey'e göre hangi fikirden ve gruptan olursa olsun herkes Meşrutiyetin ilanını gerçekleştirmek için kılıçlı ya da kılıçsız yemin etmişlerdir. Debre Mebûsu Basri Bey'in Meclis-i Mebusan'da “...Biz o yemini 10 Temmuzdan evvel yapmıştık..." ifadesi Meşrutiyet taraftarlarının Meşrutiyetin ilanında birlikte hareket ettiğini göstermektedir ${ }^{43}$. Özellikle Meşrutiyet taraftarları için ìttihat ve Terakki Cemiyeti'ne özel giriş ve yemin töreni uygulanırd ${ }^{44}$. Meşrutiyete bağ ${ }_{1} l_{l k}$ yemini Meşrutiyetin ilanından sonra da devam etmiştir. Ittihat ve Terakki Merkezi Umumisi devlet memurlarının Meşrutiyete bağllık yemini etmelerini istemiştir $^{45}$. Cemiyet, Kanun-i Esasi'nin yürürlüğe konmasından sonra, törenler tertip edilmesini ve Meşrutiyetin korunacağına dair yeminler edilmesini kararlaştırmışıtı ${ }^{46}$.

Meşrutiyetin ilanı, herkes için büyük bir gün olarak görülmüştür. Ayrıca memlekette büyük bir sevinç yaşanmasına, Meşrutî bir idareyle her alanda gelişmeler yaşanacağına, ayrılıkların ve bölünmelerin son bulacağına dair bir inanç hakim olmuştu ${ }^{47}$. Meşrutiyetin ilanından sonra Meşrutiyetin ruhuna uygun bir idarenin tesis edilememesi, onun umdelerine uyulmaması, amaçtan uzaklaşılmasına yol açmıştır. Yazar, İttihat ve Terakki Cemiyeti'nin Meşrutiyetten evvel Abdülhamit' in "istibdad" olarak nitelendirdiği idareyi yıkarak herkese adalet, müsavat ve hürriyet vereceğini vaat ettiğini, ancak Meşrutiyetten sonra bu sözlerin tatbik edil(e)mediğini belirtir. Pertev Tevfik, Cemiyetin menfî uygulamalarıyla bir "istibdad" idaresi kurduğunu, bu sebepten "vatanın tehlikede" olduğunu ileri sürer.

${ }^{43}$ Debre Mebusu Basri Bey'in Meclis-i Mebusan'daki konuşması için bkz; Tunaya, a.g.e., Cilt I, s.402-403.

${ }^{44}$ Leskovikli Mehmet Rauf, ittihat ve Terakki Cemiyeti Muhteremesine-Ittihat ve Terakki

Cemiyeti Ne Idi?, Ahmet Saki Bey Matbaası, Dersaadet, 1327, s.58-59; Kazım Karabekir, ittihat ve Terakki Cemiyeti Neden Kuruldu Nasıl Kuruldu Nasıl Idare Olundu, (haz. Faruk ÖzerenginEmel Özerengin), Türdav Ofset Tesisleri, İstanbul, 1982, s.131.

${ }^{45}$ Devlet adamlarına ve memurlarına Meşrutiyete bağlılık yemini ettirilmesi bazen kolay bazen de zorlukla yaptırılmıştır. Bkz; Selim Sırrı Tarcan, Hatıralarım, Türkiye Yayınevi, Canlı Tahliller 16, İstanbul, 1946, s.40-41; "Yemin: Sevgili Padişahımızın tebaa-yı sadıkalarına ihsan buyurdukları Kanun u Esasi ahkam-ı münifine ömrüm oldukça harfiyen itaat edeceğimi ve 32 sene mukaddem bazı erazilin ihanetiyle lağvedildiği gibi yine ilerde maazallah böyle bir hal vuku bulursa hürriyet-i vataniyenin muhafazası uğrunda kanımın son katresi akıncaya kadar Osmanlı İttihad ve Terakki Cemiyeti'ne yardım edeceğimi ve her kim cemiyet aleyhinde ika-ı fesada cür'et eylerse elimle öldüreceğimi ve bize bu lütfü bahşeden sevgili padişahımıza, din, millet ve vatanımıza kemal-i sadakat ve ubûdiyetle hizmet edeceğimi yemin ederim vallahi, billahi!" Bkz. Tarcan, a.g.e., s.31.

${ }^{46}$ Ali Cevad Bey, II. Abdülhamit'in Son Mabeyn Başkatibi Ali Cevad Bey'in Fezlekesi - II. Meşrutiyet'in ilanı ve 31 Mart Hadisesi, (haz. Faik Reşit Unat), T.T.K. Yay., Ankara, 1991, s.160.

${ }^{47}$ Süleyman Numan, "Inkılabımı", Musavver Muhit, Cilt 1, numara 9, Kanun-i Evvel 1324, s.140. 
İttihat ve Terakki Cemiyeti, kendini Meşrutiyetin tek hamisi gibi görmüş ve onu sahiplenmiştir. İttihat ve Terakki kendisini kutsal cemiyet görmüş, kendine muhalif olanları ise Meşrutiyet karşıtı olarak nitelendirmiştir. Meşrutiyetin ilanından sonra kendisini Meşrutiyetin "nigehbanı" olarak gören Cemiyet, her türlü siyasî oluşumu hiçe sayan tekelci bir tutum içine girmiştir. Meşrutiyetin ilanından sonra hürriyetin ve adaletin tesis edileceğini düşünen birçok grup, siyasî ve fikrî düşünceler ortaya koymuştur, ancak ìttihat ve Terakki hiçbir siyasî fikre llımlı yaklaşmamıştı ${ }^{48}$. Bu durum meşrutiyet ortamının gerilmesine ve kargaşaya yol açmıştır. Aslında Meşrutiyetin ilanı sonrası oluşan kargaşa ortamının en önemli sebebi, Meşrutiyetin gereği gibi anlatıl(a)maması ve anlaşı(a)maması $\mathrm{idi}^{49}$. Cemiyet de bu durumun farkına varmış, Meşrutiyetin halka daha iyi anlatılabilmesi için risaleler yayınlamış, vaizler ve Cemiyet mensuplarını bu işle görevlendirmiştir.

Tevfik Bey, Cemiyetin, muhalefeti sindirmek için baskı yaptı̆̆ını, usulsüz tutuklamalar olduğunu, gazetecilerin öldürüldügünü ifade eder. Cemiyet, kendisinin eleştirilmesini Meşrutiyete karşıtlık olarak nitelendirmiş, hiçbir eleştiriye tahammül etmemiş, eleştirilere yanıtı sert olmuştur. Muhaliflerin evlerine gece yarısı baskınlar düzenleniyor, usulsüz sorgulamalar yapılıyor, Meşrutiyetin tanıdığı can ve mal güvenliği hiçe sayılıyordu. Muhalifler gizli bir cemiyetin üyesi olmakla itham ediliyor ve Divan-1 Harbi Örfi'ye sevk ediliyorlardi ${ }^{50}$. Tevfik Bey, bunlardan Zeki Bey ${ }^{51}$ ve gazeteci Hasan Fehmi Bey'i örnek olarak verir ve bu iki kişiyi hürriyet şehidi olarak niteler ${ }^{52}$. Mehmet Murat Bey, Zeki Bey'in tutuklanışını şu şekilde anlatır: "Harem sofasındaydık. Selamlığa inmek üzere yürüdüm. Ah ü figan ile ev halkı üzerime geldiler, bir odanın kapısından içeriye itip üzerime kapıyı kilitlediler. Yüreğime korku gelmedi. Şaşkınlıktan olmalıdır ki tiyatroda bir tablo seyrediyorum gibi geldi. Yalının önüne gelmiş olan vapura bakarak pencerenin önünde durdum. Hatta kaptan ile te'ati-yi enzar ettik. Harem sofasında bir kıyamettir koptu. Kalabalıktı. iki bizim, iki Zeki Bey'in üç de merhum kayınbiraderimin olmak üzere yalnız yedi genç, yetişmiş muhaddere mevcuttu. Başka kadınlar da vardı. Şimdi bunların içine,

\footnotetext{
${ }^{48}$ Hüseyin Kami, Divançe-i Dehri, ìstanbul, 1330, s.4.

${ }^{49}$ Fethi, Muhaliflerin Esrarr, ìstanbul, 1327, s.7.

${ }^{50}$ Hafız Kemal, Cemiyet-i Hafiyye İşkenceleri Yahut Bir Sergûzeşt-i Hunin, Keteon Petrosyan Matbaası, Dersaadet, 1327, s.5.

${ }^{51}$ Zeki Bey, Prens Sebahaddin grubuna dahil olan Adem-i Merkeziyet görüşünü savunmuştur. Bkz; Süleyman Kocabaş, Jön Türkler Nerede Yanıldı (1890-1918), Vatan Yayınları, İstanbul, 1990, s.67.

${ }^{52}$ Pertev Tevfik, Vatan Tehlikede, s. 2.
} 
yani harem sofasına destursuz filansız süngülü asker hücum etmişti. Müteessir oldum her şeyi unuttum. Çıkmak üzere kapıyı vurdum. Kim işitecek?"53

11. Meşrutiyetin siyasî karmaşa/kargaşa ortamında 7 Nisan 1908 Çarşamba günü Serbesti Başmuharriri Hasan Fehmi, 31 Mart'tan 6 gün önce bir köprü üzerinde arkadaşı Ertuğrul Şakir'le yürürken öldürüldü. Ertuğrul Şakir de yaraland $1^{54}$. Tevfik Bey, gazeteci Hasan Fehmi'nin Cemiyet tarafindan öldürüldüğünü ima eder. $O$ dönemi yaşayanlarda Hasan Fehmi'nin Cemiyet karşıtı yayın yaptı̆̆ı için öldürüldüğünü ifade etmektedirler ${ }^{55}$. Hasan Fehmi'nin öldürülmesi îttihat ve Terakki yönetimine karşı tenkidi havanın oluşmasına neden olmuş, birçok itttihatçı da bu menfî ortamın tesiri ile partiden istifa etmişti $^{56}$. Hasan Fehmi'nin öldürülmesi kaygan olan siyasî zeminin fitilini ateşlemiştir. Hatta 31 Mart ihtilaline karışanların içinde Hasan Fehmi'nin hemşerileri de bulunmaktaydı. Bunların onun öcünü almak istemesi bu hadiseyi doğuran sebepler arasında zikredilmiştir ${ }^{57}$.

Tevfik Bey, devleti ve milleti mahv u perişan eden bir idare olarak nitelediği "istibdad" İttihat ve Terakki'nin uygulamalarıyla Meşrutiyetten uzaklaşarak 'istibdadî bir idare kurduğunu belirtir.

Tevfik Bey, İttihat ve Terakki Cemiyeti ile ordunun siyasete müdahale etmesini tenkit eder. Ordunun siyasetten uzak durmasını ve siyasetin sivillere bırakılmasını ister. Özellikle Süleyman Nazif Bey'in bu duruma seyirci kalmasını

53 Mehmet Murat, II. Meşrutiyet Dönemi Hatıraları, Hürriyet Vadisinde Bir Pençe-i istibdat, Enkaz-ı listibdat lçinde Bir Zügürrdün Tesellisi, Tatlı Emeller Acı Hakikatler, Latin harflerine çevirip baskıya hazırlayan Celile (Eren) Ökten Argıt, Marifet Yayınları, i̇stanbul, 1997, s.221-223.

${ }^{54}$ Mahir Sait, "31 Mart Vakası", Politika, Sayı 34, 2 Aralık 1931; Serbesti, numara 45, 29 Mart 1325, s.3; Mustafa Turan, Taşkışla'da 31 Mart Faciası, ìstanbul, 1964, s.50.

55 "Zamanın nezaketini, tuttuğumuz yolun netice-i vahimesini tahlil eylerken zamanın sebeb-i istifamız, sebeb-i iğtirabımız olan iddia-yı malumu o kadar erken, hem de kanlı bir surette teslim eyleyeceğine kani değildim. Tehlikeyi daha uzak, fakat daha ağır görüyordum. Nagehan hafi bir el bir mavzer kurşunuyla bir dimağı deldi. Kalb-i Meşrutiyeti zedeleyerek geçti. Bundan sonra fikir ve kalem mahkum-1 idam idi!... Ortada müthiş mazlum bir cinayet, Hasan Fehmi Bey, bir şehid-i mazlum!... O şenî cinayetin mürtekibi, o mahluk-ı sefil meydanda yoktu... öyle ya! Adl-i ezeli de onu icap eder. Yalnız, belki de bir hamiyyet-i mecnûnu, bir vücûd-ı mesmûmu değil! fakat; heyet-i katile-i asliyeyi ceza-dîde eder. Bu faciayı, 31 Mart hailesi takip eyliyor!", Şerif Paşa, a.g.e., s.21.

${ }^{56}$ Şerif Paşa, a.g.e., s.21.

${ }^{57}$ Ahmet ihsan, Matbuat Hatıralarım, 1888-1923, Cilt 2, Ahmet ihsan Matbaası, istanbul, 1931, s.70; lmbert, a.g.e., s.214.

58 Meşrutiyet öncesinde "istibdat" karşıtlarına göre bütün fenalıkların ve çirkinliklerin tek müsebbibi olarak Abdülhamit görülmekteydi. "İstibdat" idaresi devrilir yerine Meşrutiyet idaresi tesîs edilirde memleketin kurtulacağına inanılır. Bkz; Prens Sabahaddin, ittihat ve Terakki'ye Açık Mektuplar, Mahmut Bey Matbaası, ìstanbul, 1912, s.18. 
eleştirir. Cemiyetin kurucularının büyük bir bölümü asker kökenlidir. Bu yüzden Cemiyetteki subay sayısının hayli fazla olması nedeniyle Cemiyet "Subaylar Cemiyeti" olarak adlandırılmışı ı́ ${ }^{59}$. Zabitlerce Osmanlı İttihat ve Terakki Cemiyeti şubelerine kaydolmak bir şeref sayılmakta idi ${ }^{60}$. Bu durum Cemiyet ordu ilişkisinde önemli rol oynamıştır. Ordusuz bir Cemiyet düşünülemez ${ }^{61}$. Cemiyet-ordu ilişkisini Hüseyin Cahit farklı bir perspektiften ele almıştır: "Bu memlekette daha pek çok sene İttihat ve Terakki Cemiyeti'ne lüzûm vardır. Cemiyetin en fedakar, en gafûr, en münevver azası ise ekseriyette zabitandan ibarettir. Zabitan, Cemiyet işleriyle meşgul olmayacak olursa Cemiyet pek kıymetli bir muavenetten mahrûm kalacaktır." ${ }^{\prime 2}$ Hüseyin Cahit, ordu - Cemiyet münasebetlerinin gerekli ve lüzumlu olduğunu şiddetle savunmuştur: "Ordu, resmen Cemiyete tabi değildir. Cemiyet kulüplerine devam etmeyecek, Cemiyet ile münasebette bulunmayacaktır. Fakat aynı zamanda Cemiyetten çıkmış da değildir. Çünkü Cemiyetin, Meşrutiyeti silah kuvvetiyle müdafaa ve muhafaza vazîfesini ordu derûhte ediyor." ${ }^{\text {"3 }}$

Ordunun siyasallaşması, Il. Meşrutiyet döneminin önemli sorunu olarak görülmüştür. Özellikle 1908 seçimlerine birçok subayın katılacak olmasının doğuracağı menfî neticeleri önlemek için Harbiye Nezareti askerlerin mebus olmaları durumunda ordudan istifa etmiş sayılacaklarına dair bir tamim yayınlamıştır ${ }^{64}$. Ancak bundan bir netice elde edilememiştir ${ }^{65}$. Askerlerin siyasetten uzak durması istenmiş, ${ }^{66}$ fakat ittihat ve Terakki Cemiyeti ordunun siyasetten tam anlamıyla uzak durmasına karşı çıkmıştır ${ }^{67}$. Zira Cemiyet içinde etkin subayların olması böyle bir kararın çıkmasında etkili olmuştur. Tevfik Bey, 4 yıldır ordu-siyaset meselesinin gündemde olduğunu, fakat bunun ayrıştırıl(a)madığını ifade etmektedir (s.3).

Tevfik Bey, Cemiyetin uygulamalarıyla, hürriyet ve adaletin yerini zulm ve istibdadın aldığını, Süleyman Nazif Bey'in de bu menfî teşebbüslere ses çıkarmayıp ortak olduğunu, çıkarlarına göre kalem oynattığını ileri sürer. Fakat

${ }^{59}$ Bayur, a.g.e., Cilt 1, s.405.

${ }^{60}$ Ahmed Hamdi, Osmanlı Ordusunun Esbâb-ı Mağlûbiyeti ve Arnavutlar, Taşbaskı, Mısır, 1329, s.9.

${ }^{61}$ Tunaya, a.g.e., Cilt 1, s.28.

${ }^{62}$ Reşit Paşa, Sürgünden Intihara: Ittihat ve Terakki'nin Kurucu Üyelerinden Dr. Reşit Bey'in Hatıraları, (haz. Ahmet Mehmetefendioğlu), Arba Yay., istanbul, 1993, s.78.

${ }^{63}$ Reşit Paşa, a.g.e., s.78.

${ }^{64}$ Tanin, numara 161, 3 Kanun u Evvel 1324, s.3.

${ }^{65}$ Zabitlerce Osmanlı İttihat ve Terakki Cemiyeti şubelerine kaydolmak bir şeref sayılmakta idi.

66 H.B., "Meclis-i Mebusan ve Ordu", Ceride, numara 5, 18 Şevval 1326, s.15; Hüsamettin Karaoyvat, Hatıralar, Canlı Tarihler, Türkiye Yayınevi, İstanbul 1946, s.15.

${ }^{67}$ Hüseyin Cahid, "Ordu ve Siyaset", Tanin, numara 209, 16 Şubat 1324, s.l; Hüseyin Cahid, “Askerler ve Cemiyet”, Tanin, numara 416, 13 Teşrîn-i Evvel 1325, s.l. 
Nazif Bey, İttihat ve Terakki Cemiyeti'nin olumlu icraatlarını takdir ederken, ihmal ve hatalarını ise samimiyetle tenkit etmekten geri durmamıştır ${ }^{68}$. Hatta Nazif Bey, Meşrutiyetin beklenen gelişmeyi sağlayamamış olmasında İttihat ve Terakki'nin önemli payı olduğunu şiddetle vurgulaması, Cemiyeti rahatsız etmiştir. Nazif Bey'in Meşrutiyetten beklenen hayal ve ümitlerin yavaş yavaş ortadan kalktığını ortaya koymuş olması, ${ }^{69}$ onun çıkarına göre hareket etmediğini, dolayısıyla Tevfik Bey'in çıkarcı olarak itham etmesinin gerçekleri yansıtmadığını söyleyebiliriz. Fakat Tevfik Bey, Nazif Bey'i suçlamasına en önemli gerekçe olarak, onun beceriksiz bir idarenin yanında yer alıyor olmasını göstermektedir.

Meşrutiyet inkılabının Osmanlı milletinin mebde-i selameti olduğunu kabul eden Nazif Bey, Meşrutiyetle her şeyin düzeleceği inancının yerini ümitsizliğin aldığını, memleketin sefalet içinde boğulduğunu belirterek, dolaylı olarak Meşrutiyet idaresini tenkit eder ${ }^{70}$. Tevfik Bey'in "Süleyman Nazif Bey siz bunların ah! Bu yekunsuz fecâyi - i zalimanenin müsebbiblerini, kahramanlarını araştırmağı hesab-ı menfaatinize uyduramadınız. Şimdi döndünüz orduya, bütün millete bir feverân her muzlim emelinizi kusdunuz (tabir sizindir)" (s.4) ifadesiyle Süleyman Nazif Bey tenkit edilmektedir. Oysa Nazif Bey, İttihat ve Terakki'yi uygulamalarından dolayı eleştirmiştir. Hak gazetesindeki bir yazısında:" "Ey Babıali, ne zamana kadar sabrımızı su-i istimal edeceksin?" diyerek hükümeti tenkit etmektedir.

Amaçlarının memleketin imarına çalışmak, medenileşmek olduğunu belirten Tevfik Bey, Süleyman Nazif Bey'in (Tevfik'e göre), kendilerinin başlattığı hareketi hainlikle itham ettiğini, ancak bunun "cihad-ı hürriyet", bir uyanış ve medenileşme olduğunu belirtmektedir (s.4).

Tevfik Bey, Süleyman Nazif Bey'in “Ordu Meşrutiyetin değil, yalnız vatanın nigeh-bânıdır” ifadesini doğru bulmaz. Nazif Bey'in bu sözüne karşı şu cevabı verir: "Eğer asker vatanın nigehbânı ise vatanın yeğane nuhbe-i felâh ve terakkisi olan Meşrutiyetin de müdâfi'idir" (s.4). Aslında Nazif Bey, Meşrutiyeti sadece ordunun koruyamayacağını, onu bütün efrad-ı milletin koruması gerektiğini savunur. Tevfik Bey, İttihatçı olmamakla birlikte katıksız bir Meşrutiyet sevdalısıdır. Ona göre "Meşrutiyet olmazsa bu memleket izmihlâle uğrar." Devr-i sabıkda "bu hakikatin en feci' akıbetlerini gördük, geçirdik." diyerek Meşrutiyetin önemine vurgu yapar.

\footnotetext{
${ }^{68}$ ibrahim Alaaddin Gövsa, Süleyman Nazif: Hayatı, Kitapları, Mektupları, Fıkra ve Nükteleri, Semih Lütfi Kitabevi, ìstanbul, 1933, s.107.

${ }^{69}$ Süleyman Nazif, "Maarif ve Meşrutiyet", Yeni Tasvir-i Efkar, 9 Ağustos 1909.

${ }^{70}$ Süleyman Nazif, "Hiç", Yeni Tasvir-i Efkar, 29 Temmuz 1909.

${ }^{71}$ Süleyman Nazif, "italyanlar Hala içimizde", Hak, 8 Mayıs 1912.
} 
Meşrutiyetin ilanı üzerinden dört senenin geçtiğini, ancak Meşrutiyetten önce verilen vaadlerin hiçbirisinin gerçekleştirilmediğini belirten Tevfik Bey, Nazif Bey'e "bu deryada büyük bir mahiyet isnâd edilmezse bu dört seneyi geçen medîd bir tecrübe-i siyahın bir ra'şe-i intibâh tevlîd eylediğine i'tikad etmek lazımdır. Değil mi?" diye sormaktadır (s.5). İttihat ve Terakki'nin vatanı kurtarmak adına yaptığı olumsuz icraatlarda Süleyman Nazifin de parmağı olduğunu ileri sürer. Ancak Nazif, "Kılıçlı Siyaset" isimli makalesinde hükümet değişikliklerini, ordunun siyasete hükmetmesini ve hükümet üzerindeki tahakkümünü tenkit etmektedir ${ }^{72}$.

Tevfik Bey, 1912 seçimlerini de eleştirmektedir. Bu seçim demokrasi tarihimizde sopalı seçim olarak yerini almıştır. İttihat ve Terakki'nin baskısı altında yapılmış olan 1912 seçimlerinden Meclis-i Mebusan'a İttihatçı mebuslar ezici bir çoğunlukla girmiştir. 1912 seçimlerinde memurlar, İttihat ve Terakki müttefiki gibi çalışmışlar, böylece muhalefet hem Meclis-i Mebûsan'dan silinmiş, ${ }^{73}$ hem de nerede ise susturulmuş ve sindirilmişti ${ }^{74}$. Tevfik Bey, seçimin adil olmadığından dolayı genel temayülün Meclis'in feshinden yana olduğunu belirtmektedir. 1912 seçimlerini "yirminci asır medeniyeti için hatıra-i millette, hükümet-i ittihadiye namına, ezeli bir devre-i mezalim ve hıyânetin canlı bir şahid mutantanıdır" diye tanımlamaktadır(s.5 $)^{75}$.

Tevfik Bey, mebusların bulundukları makamın hakkını vermediklerini, hakikatlere ve millet yararına göre hareket etmediklerini ve çalışmadıklarını, hükümetin her türlü olumsuz ya da olumlu işlerine onay verdiklerini, bu şekilde bir tavır sergileyen Meclis'in milleti temsil etme hakkına sahip olamayacağını ileri sürmektedir. Seçimlerin usulsüzlüklerinden bahseden Tevfik Bey, "Nerede kaldı intihabat?" diye sorar. Özellikle İttihat ve Terakki'nin tahakkümü altında yapılmış olan 1912 seçiminin, hak ve adaletle yapılmadığından, tayin ve zorlama ile yapıldığından bahseden Tevfik Bey, böyle bir seçimi Meşrutiyetin ruhuna uygun bulmadığından dolayı tenkit eder. Bu tür usulsüzlüklerin millet için büyük bir talihsizlik olduğunu söyler (s.6).

Tevfik Bey, Süleyman Nazif ve Babanzade i̇smail Hakkı Beylere "Bu diyar-ı harabda kanunsuzluk, hükümetsizlik, sefâlet-i idareye vicdânlara kadar yükseldiği erbâb-ı namus nevmîd ferdâ ye's içinde bunaldı̆ı demlerde nerede idiniz. Kanun namına bu tafraları bu asabiyeti niye o zaman göstermediniz" diye sormakta ve

\footnotetext{
${ }^{72}$ Süleyman Nazif, “Kılıçı Siyaset”, Hak, 25 Temmuz 1912.

${ }^{73}$ Lütfi Fikri, "Memurun Siyasetle işstigali Meselesi", ifham, numara 299-115, 26 Haziran 1328,s.1.

${ }^{74}$ Lütfi Fikri, "Memurinin Siyasetle îştigali Zarurî Olan Zamanları", Tazminat, numara 324, 4 Ağustos 1328, s.3; Lütfi Fikri, "Buhran-1 Vükela ihtimalinin Sebebi", Tazminat, numara 328, 8 Ağustos 1328, s.l.

${ }^{75}$ Tunaya, a.g.e., Cilt 1, s.39.
} 
$74^{*}$ TAED 45 T. ASLAN

tenkit etmektedir. Tevfik Bey, İttihatçıların hakim olduğu Meşrutiyet hükümetinin yaptı̆̆ı menfî uygulamalara rağmen, yine de bir ümit taşıdığını belirtir (s.6).

Tevfik Bey, İttihat ve Terakki'nin siyasî ve idarî uygulamalarının vatanı tehlikeye ittiğini ileri sürer. Bundan dolayı ortaya çıkan müşkül durumun bir an evvel ortadan kaldırılmasının gereğine değinir. Bu duruma ses çıkartılmadıkça ittihat ve Terakki'nin zayıfları ezmeye devam edeceğini belirtir. Tevfik Bey, bu durumu engellemek için şiddetli gösteriler yapılmasını önerir. Bunun daha da genişleterek milletin ve ordunun da karıştırılmasıyla İttihat ve Terakki iktidarının ortadan kaldırılmasını arzu ettiği görülmektedir. Onun bu anlayışını demokrat kimliğiyle bağdaştırmak mümkün değildir. Ordu ve halkı bu teşebbüse müdahil kılmak ihtilalden başka bir şey değildir. Böyle genel bir isyan hareketine dair yazılar kaleme almasını kendi düşüncesi olarak değerlendirmemek gerekir. Bunun arkasında ittihatçı muhaliflerinin parmağı olduğunu söyleyebiliriz. Zira Paris'te İttihat ve Terakki muhalifi Şerif Paşa, muhalif hareketin finansman kaynağıydı ${ }^{76}$.

Tevfik Bey, ordunun ve milletin iştirak ettirileceği isyanı "Böyle bir cidal muhteşem hürriyet" şeklinde ifade eder. Bunu tarihteki Kabakçı Mustafa isyanlarıyla da desteklemeye çalışır (s.6).

\section{Pertev Tevfik Bey'in 'Vatan Tehlikede' ìsimli Risalesinin Metni}

Muharrir ve Naşiri

G. Pertev Tevfik

VATAN TEHLIKEDE

istanbul 21 Temmuz 1328

[2] Bir Muhteşem Cidâl

Meşrutiyet için kılıçlı kılıçsız hep yemin ettik.

Müthiş bir cilve-i şuûndur, bu mülkte medeniyet, insaniyet namına tüyleri ürperten sefil bir tarz-1 idareyi tesis azmiyle merdûd her emeli, kara korkunç her fikri, hasılı te'mîn-i menfaat-ı hasîseye hâdim her vasıtayı bir hırs-ı fazîh tatmin ile irtikâb eyleyen surata meşrût bir "itttihad Hükümeti" namı altında hakikatte ise vicdangüdaz bir hükümet-i vahşiyeden başka bir şeyi temsil etmeyen idare-i sâbıka-i erkân ve bilhassa o ricalin mutîa ve ümitvar taraftarları -ni'met şinâslık olacak- el'an "Kılıçlı Siyaset" "Nakarât-ı neşîde-i iğtişâş" terennümâtıyla demgüzârdırlar. "Bizans'ın bir irtiâş̧-ı ihtirâs" elleri diye binlerce Osmanlıya bir

\footnotetext{
${ }^{76}$ Ahmet Bedevi Kuran, Osmanlı imparatorluğu'nda Inkılap Hareketleri ve Milli Mücadele, Çeltüt Matbaası, ìstanbul 1959, s. 477.
} 
nazar-1 kindâr tezyîf ile bakan "Hak" muharriri isimleri mahkeme-i cinayet salonlarında zavallı şehit içtihat Zeki Bey'in mahkemesi dolayısıyla kirlenen eşhâsa ve dahası var. Şehit bülend-i hürriyet Hasan Fehmi, Samim için vicdan-ı millette yine o şahıslara karşı hazîn bir hatıra-i hûnîn yatarken o şühedâ-yı hürriyetin üfûl hûnîniyle münasebetdar tanılan simalara birer mersiye, birer müdafaa yazmaktan adeta haz alıyoz.

Cihana vicdana karşı irtikab edilen o fazîhane cinayetlerin en hudûsunda hâmelerinin kıymet-i edebiyesini olsun denemek zahmetini ihtiyâr etmeyen bu kıskanç hürriyetperverlerin vatanımız cidden her türlü mehâlike, her türlü mesâibe ma'rûz iken kalemlerine bir sırr-ı muahezekâr vermeleri müdâfaa eder göründükleri prensiplerin ve bilhassa kanunun biraz daha yükseliniz(?), bu zavallı vatanın kendileriyle rütbe-i münasebetini pek güzel ta'yîn eder.

Efendiler! Bu memlekette kanun çamurlarda, zalim kucaklarda gezerken, vatanı düşünmek meşrutiyeti müdafaa eylemek hıyanet, hatta cinayet telakki olunurken nerede idiniz? Niçin, niçin sustunuz?

Hak namına icâle-i kalem eylemek iddialarıyla cihanı dolduran velvelecilerin mesnedleri, her halde çok sürmez tarihte görürüz. Patrona Halillerden, Kabakçı Mustafalardan hatta Fehim Paşalardan fikren değilse bile emelen yüksek olmayan bir şirzime-i ma'lûme olmamalıdır. Efendiler! Osmanlılığın tarih-i meşrutiyetinde haşre kadar silinmez bir şaibe-i tagallüb olan devr-i sabıkı senelerce birkaç şahsın dest-i i'tisâfında bu muhit-i mahzûne elemengiz bir ömür sefâlet yaşatan [3] o devr-i hûn ve ateş tarac emeliyle çalşsan zümre-i rehâ-kârı ve bütün bir milleti taşlamak hakkını o mâzî-i meş'ûm sefaletimizden sildi süpürdü. Şimdi size sükût, biraz intizâr düşer. Hiç olmazsa bir lahza-i i'tidâlinizi bu vatana edilen o bî-pâyân nankörce hıyanetlerden sonra yalnız biricik fakat son kıymetdâr bir hidmet diye ibrâz edebilirsiniz. Çünkü bu günün sefâletleri, mahrumiyetleri hasılı her türlü tecelliyâtı dünün şeâmetlerinden mezâliminden hep o bî-pâyânsız seyyiâtından doğdu. Doğuyor. Bu günkü müz'ic, ızdırâbengiz tezahürât dünkü bi-vicdân saltanat-ı ucube-i ittihadiyenin elim akibetleri.

\section{Kılıçlı Siyaset}

Yıldız hükümeti, Osmanlı İmparatorluğu'nu taç ve taht-ı Osmaniyi nihayet pek mühlik bir dereke-i helâka kadar yuvarladığı, vatanımızda kesîf bir mutlakiyet altında hacîl bir idareyi bütün kerâhetiyle pâyidâr eylediği berdemde efkâr-1 âmme-i millete müzâheret eyleyen orduyu Süleyman Nazif Bey halâskâr vatan addederken 10 Temmuz ferdâsını bir sabah felâh telâkki eylerken bugün o tarz kadim mutlakiyetin bir nev'-i müşevveş değerini ihya eyleyenlere karşı yine o ordu kat'i, samimi darbe-i rehâver atınca senelerin bar menâfi' ile cihanı, bir cihan-ı menfaat gören o muharrir bu sefer dönüyor, İttihad ve Terakki Cemiyeti 
yani biz "ölümden değil, tarihten korkarız, korktuk", safsatalarını fakat neden sonra yazmaktan çekinmiyor.

İttihad ve Terakki Cemiyeti'ne muhalifler dört senedir ordunun siyasetten çekilmesini âmâl-i sakîmeye menâfi'-i zelîleye alet gösterilmemesini ehemmiyetle tavsiye ederlerken acaba Süleyman Nazif Bey, Patrona Halillerden, Kabakçı Mustafalardan, Yeniçeri kazan kaldırmalarından bi-haber mi idi? Bu hakayık-ı basîteye bu demde güya bir cesaret-i medenîye ibrâz eder tarzda dört süslü kelime ile ifade etmekte meziyet görmek için evvel emirde bu efkârın kaili Süleyman Nazif Bey olmamalıdır.

Çünkü, Nazif Bey siz bu mülkü, yine yalnız sizin meşrutiyet ıtlak ettiğiniz devirde, şarktan garba dolaştınız, tarihten korktuğunu iddia eylediğiniz o cemiyet-i mahûfenin cinayatdan ürkmediğini, İstanbul sokaklarında parçalanan zavallılardan ibretle anlayamadınız, bu bağrı yanık milleti taraf taraf her gün bin şeâmetle bitiren bela-yı mahz-ı kail bedbahtlarını hiç düşünmediniz. Çünkü ne hesabınıza, ne ikbâlinize uyardı. Makalenizde sırasıyla dizdiğiniz şu: "Afrika-yı Osmanî yüz elli bin ìtalyan askerinin dişleriyle parçalanırken, adalardaki hakimeyet-i Osmaniye İtalya'nın ayaklarıyla [4] çiğnenirken payitahtın medhal-i müstahkeme -büyük zırhlıların değil- küçük torpidoların istihfâf-kâr hücumlarıyla tezlîl edilirken" müsaade ederseniz biraz da ben söyleyim. İntihabat diye millet-i Osmaniye gayr-ı baştan(?) geçirilirken irtica' bahanesiyle Langaza'da vatandaşlar parçalanırken hasılı bu mülk haricen afet, dahilen sefalet içinde bu yangın Süleyman Nazif Bey siz bunların ah! Bu yekunsuz fecâyi' - i zalimanenin müsebbiblerini, kahramanlarını araştırmağı hesab-ı menfaatinize uyduramadınız. Şimdi döndünüz orduya, bütün millete bir feverân her muzlim emelinizi kusdunuz (tabir sizindir).

Arnavutluk dağlarının şâhikalarında, bu memleketin -eğer varsama'mûrelerinde yahud şehirlerinde îka' olunan fazâyih-i idareye ve harîs ellerle îkad edilmiş bir nâire-i fesâd sâikasıyla cebhe-i millete bütün cihan-ı temeddüne karşı sürüklemek istenen şâeye-i nâmus-ı tathir ediliyor. O rehâ-kâr cidâl-ı i'tilâ'-1 cûyânenin eser-i feyyâzı bütün mülkçe, milletçe ta'kib olunur. Ve bu şahane-i hareket dediğiniz gibi bir hıyânet değil, asla değil! Bilakis temeddün, insaniyet, fazilet, intibâh namına şâyân-ı şükrân şâyân-1 ihtirâm bir hidmettir. Bir cihad-ı hürriyettir.

\section{Süleyman Nazif Bey!}

“Hayır, ordu meşrutiyetin değil, yalnız vatanın nigeh-bânıdır." Demekle bilmem ne ifade ediyorsunuz. Birkaç şahıs, vatanımız, yukarıda saydığınız gibi haricen bin musîbete ma'rûz iken dahili düşmanların cüret-i sefilanesi bu mülkün her emel-i halâsını çiğnerken bu vatan müdâfi'leri vazife-i müdafi'lerini yerine getirmemeli mi? Ĕger asker vatanın nigehbânı ise vatanın yeğane nuhbe-i 
felâh ve terakkisi olan meşrutiyetin de müdâfi'idir. Çünkü meşrutiyet olmazsa bu memleket izmihlâle uğrar. Nitekim düne kadar bu hakikatin en feci' akıbetlerini gördük, geçirdik.

Eğer Cemiyet-i İttihadiye cidden tarihten korkar. Rüfeka'nız irfândan, faziletten çoktan vazgeçtik. Fakat biraz vicdandan tehâşî eyler. Takımdan olsa idiler yukarıda yine sizin makalenize bir fikr-i igvâ' ile dizdiğiniz seyyiât-ı hazırayı tevlîde var kuvvetle azm eylemez. Bu mülkü bu hale bu hal-i perişaneye ilka etmezdi.

Yine siz heyet-i inhisâriye bir nebze tarihten, bütün atinin bir garez ve kin sizlere ithâf eyleyeceği menâkıb-ı müdhişeden ictinâb etseniz böyle bu anda dört tarafa saldırmaz, daire-i maznûniyetten böyle nâ-gehân kürsî-i hakimiyete fakat bu biraz mezbû-hâne - sıçramak meylini göstermezdiniz.

Bu gün o heyet-i inhisâriyeye düşen gayr-1 milliye bir nefs-i huzuru olsun kıskanmamak hiç olmazsa bu bedbaht vatanı hala benimsememektir. [5] Dört parça eşya için hürriyet aleyhine isti'mâl olunmuş bir silâh-ı ihânet telakkisiyle müsaid zihniyet eshâbına gayr-ı bu deryada büyük bir mahiyet isnâd edilmezse bu dört seneyi geçen medîd bir tecrübe-i siyahın bir ra'şe-i intibâha tevlîd eylediğine i'tikad etmek lazımdır. Değil mi?

Serîr-i hissiyât-ı milletten taşan seyl-i efkârın ihtişâm tevsi'ine sefil vesait ile (?) olunamayacağı şimdi bittecrübe sabit ise Süleyman Nazif Bey gayrı i'tidâlinizi ahz ediniz, igvâ'atınızı ise altı ay sonra ikame edeceğinizi bir ümit vaad eylediğiniz hükümet-i mahalliyenin ferda-yı i'lânında isti'mâl edersiniz.

Rical-i ittihadın tatmin olunamayan âmâl-i ihtirası meydanda dururken Osmanlı ordusundaki kasd etdikliğiniz dalavereler arasında vatanı bir buğday tarlası derekesine indirecek, yine açlıktan ölmek korkusuyla dediğiniz neviden kahraman taslaklı̆̆ edecek bir ferd yoktur. Bu son cidal muhteşem hürriyetin harîm ulviyete parmaklarınızla hissiyat-ı mülevvese bulaştırmaktan bilmem ne haz duyardınız. Bu cüretinize de "yalnız utanmak ve yalnız ağlamak kifayet etmez."

\section{Neşîde-i iğtişaşın nakarâtı}

Yani ekseriyet milletin bu Meclis-i Mebusan'ı fesh ettirmek azm-i kat'îyesinde bulunması. Çünkü bu Meclis gayr-ı meşru, gayr-ı kanunî... Çünkü bu Meclis azası ârâ-yı hakikiye-i milleti hâmil değil! Hasılı bu Meclis efendiler! Yirminci asır medeniyeti için hatıra-i millette, hükümet-i ittihadiye namına, ezeli bir devre-i mezalim ve hıyânetin canlı bir şahid mutantanıdır.

Bir zamanlar bu memlekette ihanet, cinayet, kanunsuzluk, işkenceler, suçlar, silahlar hal-i faaliyette idi. Hükümferma idi. Bu türlü eyyem-1 mesâibin, zulm ü sefaletin o Meclis bir zade-i halâsdır. 
Kanunperestliğe, milletperverliğe salâha bâ-husûs hürriyet esaslarına sarılacak yeni bir idare, meşrût bir hükümet için züll bir şâeye teşkil eden böyle bir hata-yı mahzûle teşrîk-i mesâî eyleyemez. Vicdan-ı ammeye istinâden tedvîr-i mehâmm umura yeltenecek bir hükümet-i meşrûtanın matma'-ı nazarı, pîş-gâh -1 inzâr-1 millette hala hakaret-âmîz bir vaz'-1 müz'ic ısrâr alan o türlü bir meclis Fransa inkılabının şa'şaa-dâr safhalarını yarım yamalak fakat gülünç taklide uzanan yalancı mirabolarıyla? iade eylemektir.

Mirabo "Biz buraya ârâ-yı milletle toplandık. Ancak süngülerinizle dağıtabilirsiniz!" demişti. Demişti fakat bu hitâbe-i celâlet bir krala, bir gayr-1 mes'ûle hasılı saltanat-ı âmmeye rağmen hükümrân olmak isteyen bir şahsiyete karşı fırlatılmıştı. Onun içindir ki bu mütâlaa-i muhteşeme hakikatte müessir idi. Asîl-âne tanındı. Fakat bugünküler o hitâbeyi hâkimiyet-i âmmeye, umum efkâr-ı millete rağmen îrâd eyliyorlar. Onun içindir ki bir meziyeti, bir hükmü olamaz.

[6] Daha bir gün evvel Vükelâ-yı Devletin Meclis'e okuduğu beyannamede şemme-i istiskal olsun hissetmeyecek kadar safdillik -kelime hakikatte pek hafiftir!- gösterin. Sırf idâme-i mevcudiyet emelleriyle her şeye evet beyan bir Meclis şüphesizdir ki vekâlet-i milleti hâiz olamaz. Nerede kaldı ki intihâbât. Daha doğru bir ta'bir ile, ta'yîn cebreden mütevvellid vâ-veylâ hazîn millet henüz sâmialarda ra'şe-dâr nekbettir.

Nihayet.. Süleyman Nazif ve Babanzade İsmail Hakkı Beğler! Bu diyar-ı harabda kanunsuzluk, hükümetsizlik, sefâlet-i idareye vicdânlara kadar yükseldiği erbâb-ı namus nevmîd ferdâ ye's içinde bunaldığı demlerde nerede idiniz. Kanun namına bu tafraları bu asabiyeti niye o zaman göstermediniz..... Cihanda hâlâ menâfi'-i umumiyeye rağmen bütün kerâhetiyle pây-dâr olan bu sefil menfaat!

Hep bu neşâid-i iğtişaşın nakaratı.

Muhteşem bir cidâl-1 insâniyet-perverâneye karşı tahşîd iden bir sürü menâfi'-i zâtiyenin ihtimâl üfûli yüzünden gazetelerinizde cây-1 tekrar buluyor. Fakat, gayr-1 emîn olunuz. Bedbaht Osmanlılı̆̆ın sine-i safında teşne-i terakki, teşne-i ümîd rehâ bir kalb-i selîm insâniyet çarpmaya başladı. Ve gayr-1 i'sâr-1 sâlifenin bütün şeâmetlerini alkışlamakla me'lûf tanıdığımız Bizans'tan tutunuzda en ücra bir köşesine kadar bütün Osmanlılıkta feyyâz bir vicdân-ı inkişâf eyledi. Öyle olunca da siz Bizans'ın bu ca'li hamiyet - perverânı! Şuûn-1 sâlifenin lezzet-i yadıyla orada, o bulunduğunuz nokta-i teannüd de "ölümden değil tarihten" korkmak didinmeleri içinde kalacaksınız.

Bütün Osmanlılık değil, altı ay sonra bu mülk nuhbe-i garra-yı halasına erişir. Gayrı o hengame sizin için yeniden tesis-i hükümet cilve-i meş'ûmunu ibrâz eylemez zannındayım. 
Sizin için bu yaygaralarınızdan daha değerli, daha ağır baş bir hareket vardı. Vatanımızı tehlikeler arasında üzmemek! Mamafih, bilinmez şuûn-ı alim-i acebidir dünün kahramanı idiniz, yarınında ölüverirsiniz. Yine zannımca böyle bir tebeddül hiç olmazsa bu memlekette tek bir namuslu adamın kalmamasını mütevakkıf.

\section{Efendiler!}

Vatanın cidden tehlikede olduğunu, müşkülât-ı hazıranın defi en evvel i'tidâle ihtiyaç gösterdiğini takdir edemez değilsiniz. Sükût edildikçe zebûnküşane muhâcemeler, şedîd göstermedikçe kahramân-âne nümayişler bilmem ki bu kıymet-i ahlakiyeyi haiz olabilir mi? Bu gün evvelemirde millet, sonra ordu, hasılı hep beraber seyyiât-ı sabıkayı ber-taraf etmek üzereyiz. Böyle bir cidal muhteşem hürriyet. 10 numaradaki şâbâşları şayan görmeseniz bile, cihana Kabakçı Mustafa yaldızlarıyla bu hakikat arz ediyor görünmemeye imkân bulabilirsiniz.

\section{Sonuç}

Pertev Tevfik Bey, Osmanlı Devleti'nde Meşrutiyetin tam manasıyla tatbik edilmesini arzu eden bir Osmanlı aydınıdır. Risalede, Meşrutiyetin ilanı ile memlekette adaletin, hürriyetin ve eşitliğin sağlanacağını vaat eden İttihat ve Terakki Cemiyeti'nin, kendisinden başka hiçbir siyasî görüşe hayat hakkı tanımayan tekelci tutumu eleştirilmektedir. Tevfik Bey, risalede adalet, seçim, hukuk, eşitlik, siyasî cinayet, meşrutiyet, demokrasi vb. konuları ele almıştır. Risalede Tevfik Bey'in ele aldığı hususlardan şu neticeyi çıkartabiliriz;

1. Pertev Tevfik Bey, Osmanlı Devleti'nde Meşrutiyetin hiç kimsenin tekelinde olmadığını ve onun tek sahibinin Osmanlı milleti olduğunu vurgulamıştır.

2. Pertev Tevfik Bey, İttihat ve Terakki Cemiyeti'nin tekelci ve baskıcı bir idare tesis ederek, sabık devirden daha baskıcı olduğu kanısındadır.

3. Ona göre Cemiyet, tutum ve uygulamalarıyla Meşrutiyet umdelerinden uzaklaşmışırır. Cemiyetin muhalefeti sindirmeye çalışarak Meşrutiyeti amacından uzaklaştırmış, baskıcı tutumuyla ve usulsüz tutuklamalarıyla despot bir tutum içine girmiştir.

4. Pertev Tevfik Bey'in, risalede ele aldığı hususlara bakarak; vatanın ilerlemesi ve gelişmesi için çaba sarf eden bir demokrat olduğunu ifade edebiliriz. Ancak Tevfik Bey'in Itttihat ve Terakki iktidarının uygulamalarına şiddete kapı açabilecek, toplumda kargaşa oluşturabilecek nümayişler önermesi doğru bir düşünce değildir. $\mathrm{Bu}$ anlayış, onun ihtilalci bir karakter taşıdığını ve demokratlıkla örtüşmediğini göstermektedir. Bu durum onu haklı iken haksız duruma düşürmektedir. Zira demokrasinin neşv ü nema bulmadı̆̆ı ortamda yapılacak gösteriler büyük taşkınlıklara yol açabilir ve bir isyan hareketine 
$80^{*}$ TAED 45 T. ASLAN

dönüşebilir. Mevcut idareyi ortadan kaldırma adına halkı galeyana getirecek hareketler, toplumun huzurunu bozacağı, iç güvenliği tehdit edeceği ve çözüm değil çözümsüzlük getireceği için hiçbir şekilde hoş görülemez.

5. Osmanlı Devleti'nde sivil bir idarenin tesis edilmesinin gereğini savunan Tevfik Bey, ordunun siyasete müdahale etmesini şiddetle eleştirmiştir. Ordunun siyasetten uzak durmasıyla, Meclis-i Mebusan üzerindeki baskının ortadan kalkacağını savunmuştur. Orduyu mevcut iktidarı ortadan kaldırma adına ihtilal yapmaya teşvik etmesi bu anlayışıyla bağdaşmamaktadır.

6. Tevfik Bey, usulsüz tutuklamalarla kişi hak ve özgürlüklerinin çiğnenmesinin, kanunlara aykırı bir durum olduğunu belirtmiştir.

7. Süleyman Nazif Bey'in Cemiyetin uygulamalarına ses çıkartmadı̆̆ına dair suçlamaları, hakikati yansıtmamaktadır. Süleyman Nazif Bey, İttihat ve Terakki Cemiyeti'nin müspet uygulamalarını takdir eden, menfi uygulamalarını da tenkit etmekten geri durmayan bir vatanperverdir.

\section{KAYNAKÇA}

Arşiviler

Arşiv Belgeleri [Başbakanlık Devlet Arşivleri Genel Müdürlüğü Osmanlı Arşivi (BOA)]

BOA, DH.EUM.KADL., 1/12.

BOA, DuiT (Dahiliye Usulü İradeler Tasnifi), 49/11-3-5/3/1, 2.

BOA, Y.EE (Yıldız Esas Evrakı), 86/32, sıra no: 3186.

BOA, YEE (Yıldız Esas Evrakı), 23/1792.

Süreli Yayınlar
Ceride
Davul
Hak
lşık Dergisi
ifham
ikdam
Muahede
Muhit
Politika
Sabah
Serbesti
Tanin
Tazminat
Yeni Tasvir-i Efkar

Makaleler

"Hürriyet Nedir?", Davul, 21 Teşrîn-i Evvel 1324.

"Vatandaşlarımızı Tebrik”, lşıı Dergisi, numara 3, ístanbul, 1325.

Abdülhak Şinasi, "Süleyman Nazife Dair Hatıralar", Muhit, no 29, Mart 1931.

H.B., "Meclis-i Mebusan ve Ordu", Ceride, numara 5, 18 Şevval 1326. 
Pertev Tevfik ve 'Vatan Tehlikede' İsimli Risalesi

TAED

Hüseyin Cahid, “Askerler ve Cemiyet”, Tanin, numara 416, 13 Teşrîn-i Evvel 1325.

Hüseyin Cahid, "Ordu ve Siyaset", Tanin, numara 209, 16 Şubat 1324.

Lütfi Fikri,“Buhran-1 Vükela ihtimalinin Sebebi”, Tazminat, numara 328, 8 Ağustos 1328.

Lütfi Fikri, "Memurinin Siyasetle işstigali Zarurî Olan Zamanları", Tazminat, numara 324, 4

Ağustos 1328.

Lütfi Fikri, “Memurun Siyasetle İștigali Meselesi”, ifham, numara 299-115, 26 Haziran 1328.

Mahir Sait, "31 Mart Vakası", Politika, Sayı 34, 2 Aralık 1931.

Pertev Tevfik, "Bizde Matbuat", Muahede, numara 8, 12 Teşrin-i evvel 1326.

Pertev Tevfik, "Intizam Vazife", Muahede, numara 9, 13 Teşrin-i evvel 1326.

Pertev Tevfik, "Muahede'nin Tefrikası: Demokrasi 1", Muahede, numara 19, 1 Kanun-1 evvel

1326.Süleyman Nazif, "Bursa'da Salihanizade Ragıb Beyefendiye Cevab”, Hak, 31 Mart 1912.

Süleyman Nazif, "Hiç", Yeni Tasvir-i Efkar, 29 Temmuz 1909.

Süleyman Nazif, "ítalyanlar Hala içimizde", Hak, 8 Mayıs 1912.

Süleyman Nazif, "ittihat ve Terakki'de Celal Nuri Bey”, Hak, 27 Mart 1912.

Süleyman Nazif, "Kılıçlı Siyaset", Hak, 25 Temmuz 1912.

Süleyman Nazif, "Maarif ve Meşrutiyet", Yeni Tasvir-i Efkar, 9 Ağustos 1909.

Süleyman Numan, "Inkılabımız", Musavver Muhit, Cilt 1, numara 9, Kanun-i Evvel 1324.

\section{Telif Eserler}

Ahmad, Feroz, Ittihat ve Terakki (1908-1914), (çev. Nuran Yavuz), Kaynak Yayınları, İstanbul, 1984.

Ahmet Hamdi, Osmanlı Ordusunun Esbâb-ı Mağlûbiyeti ve Arnavutlar, Taşbaskı, Mısır, 1329.

Ahmet ihsan, Matbuat Hatıralarım, 1888-1923, Cilt 2, Ahmed ihsan Matbaası, ìstanbul, 1931.

Ahmet Ziya, Meşrutiyet Uğrunda, Yeni Osmanlı Matbaa ve Kütüphanesi, i̇stanbul, 1327.

Ali Cevad Bey, II. Abdülhamit'in Son Mabeyn Başkatibi Ali Cevad Bey'in Fezlekesi - II. Meşrutiyet'in Ilanı ve 3 I Mart Hadisesi, (haz. Faik Reşid Unat), T.T.K. Yay., Ankara, 1991.

ALKAN, Ahmet Turan, II. Meşrutiyet Döneminde Ordu ve Siyaset, Cedit Yayınları, Ankara, 1992.

ALTINAY, Ahmet Refik, Inkılab-ı Azim, Asır Matbaası, istanbul, 1324/1908.

BAYUR, Yusuf Hikmet, Türk Inkılabı Tarihi, Cilt 1,2,3, T.T.K., Ankara, 1991.

BEYSANOĞLU, Şevket, Doğumunun 10o. Yılında Süleyman Nazif (Hayatı, Sanatı, Eserlerinden Seçmeler), Ankara, 1970.

BirinCi, Ali, Hürriyet ve İtilaf Firkası, Dergah Yayınları, ìstanbul, 1990.

BiRiNCi, Ali, Tarihin Gölgesinde, Dergah Yayınları, ìstanbul, 2001.

Ekrem Reșad - Osman Ferid [Sağlam], 10 Temmuz Hatırası, 1325 Sene-i maliyesine Mahsûs Nevsal-i Osmanî, Matbaa-i Ahmet ihsan, istanbul, 1325.

Fatma Teryal, Hakikat, Cilt 1, ìstanbul, 1325.

Fethi, Muhaliflerin Esrarı, ìstanbul, 1327.

GÖVSA, ibrahim Alaaddin, Süleyman Nazif: Hayatı, Kitapları, Mektupları, Fıkra ve Nükteleri, Semih Lütfi Kitabevi, ìstanbul, 1933.

Hafiz Kemal, Cemiyet-i Hafiyye İşkenceleri Yahut Bir Sergûzeşt-i Hunin, Keteon Petrosyan Matbaası, Sirkeci Hoca Paşa, Dersaadet, 1327.

Hasan Amca, Doğmayan Hürriyet, Sıralar Matbaası, istanbul, 1958.

Hüseyin Kami, Divançe-i Dehri, ìstanbul, 1330.

IMBERT, Paul, Osmanlı Imparatorluğu'nda Yenileşme Hareketleri, (Türkiyénin Meseleleri), (çev. Adnan Cemgil), Havass Yayınları, ìstanbul, 1981.

KARABEKIR, Kazım, ittihat ve Terakki Cemiyeti Neden Kuruldu Nasıl Kuruldu Nasıl idare Olundu, (haz. Faruk Özerengin-Emel Özerengin), Türdav Ofset Tesisleri, İstanbul, 1982.

KARAKAŞ, Şuayb, Süleyman Nazif, KB, Ankara, 1988.

KARAOYVAT, Hüsamettin, Hatıralar, Canlı Tarihler, Türkiye Yayınevi, İstanbul, 1946. 
KOCABAŞ, Süleyman, Jön Türkler Nerede Yanıldı (1890-19ı8), Vatan Yayınları, ìstanbul, 1990.

KURAN, Ahmet Bedevi, Osmanlı imparatorluğu'nda Inkılap Hareketleri ve Milli Mücadele, Çeltüt Matbaası, İstanbul, 1959.

KUTAY, Cemal, Prens Sabahattin Bey, Sultan Il. Abdülhamit, ittihat ve Terakki, Tarih Yayınları, istanbul, 1964.

Leskovikli Mehmet Rauf, Ittihat ve Terakki Cemiyeti Muhteremesine-Ittihat ve Terakki Cemiyeti Ne Idi?, Ahmet Saki Bey Matbaası, Dersaadet, 1327.

M.Z., Ittihat ve Terakki Cemiyeti'nin Firıldakları yahut Tarih-i Matem, ìstanbul, 1328.

Mehmet Murat, II.Meşrutiyet Dönemi Hatıraları, Hürriyet Vadisinde Bir Pençe-i Istibdat, Enkaz-ı istibdat lç̧inde Bir Zügürdün Tesellisi, Tatlı Emeller Acı Hakikatler, (hazırlayan Celile (Eren) Ökten Argıt), Marifet Yayınları, istanbul, 1997.

Mehmet Memduh Paşa, Feveran-ı Ezman, Vilayet Matbaası, İzmir, 1915.

Mustafa Turan, Taşkışla'da 3l Mart Faciası, İstanbul, 1964.

Pertev Tevfik, Vatan Tehlikede, Manzume Matbaası, ìstanbul, 1328.

Prens Sabahaddin, Ittihat ve Terakki'ye Açık Mektuplar, Mahmut Bey Matbaası, İstanbul, 1912.

Reşit Paşa, Sürgünden Intihara: Ittihat ve Terakki'nin Kurucu Üyelerinden Dr. Reşid Bey'in Hatıraları, (haz. Ahmet Mehmetefendioğlu), Arba Yay., Istanbul, 1993.

Şerif Paşa, Bir Muhalifin Hatıraları -itttihat ve Terakkiye Muhalefet-, Nehir Yayınları, İstanbul, 1990.

TARCAN, Selim Sırrı, Hatıralarım, Türkiye Yayınevi, Canlı Tahliller 16, ìstanbul, 1946.

TÖKiN, Firuzan Hüsrev, Türk Tarihinde Siyasi Partiler ve Siyasi Düşüncenin Gelişmesi, Elif Yay., İstanbul, 1965.

TUNAYA, Tarık Zafer, Türkiye'de Siyasal Partiler, Cilt 1, iletişim Yayınları, ìstanbul, 2007.

TUNÇAY, Mete, Türkiye'de Sol Akımlar, Cilt I, Bilgi Yayınevi, İstanbul, 1978.

VARDAR, Galip, Ittihat ve Terakki lçinde Dönenler, (haz. Samih Nafiz Tansu), Yeni Zamanlar, istanbul, 2003.

YALÇIN, Hüseyin Cahit, Talat Paşa, Yediğün Neşriyat, İstanbul, 1943. 